\title{
Effect of Smartphone Use on Neck Pain and Disability Level in University Students Who Exercise Regularly: A Comparative Study
}

\section{Düzenli Egzersiz Yapan Üniversite Öğrencilerinde Akıllı Telefon Kullanımının Boyun Ağrısı ve Özür Düzeyine Etkisi: Karşılaştırmalı Bir Çalışma}

\author{
Feride Yarar $^{1}$, Fatih Tekin ${ }^{1 *}$, Nesrin Yağc1 ${ }^{1}$, Seçil Topal ${ }^{1}$ \\ ${ }^{1}$ Pamukkale University, School of Physical Therapy and Rehabilitation, Denizli, Türkiye. \\ e-mail: feridebeydemir@hotmail.com, fzt.ftekin@hotmail.com,nyagci@pau.edu.tr, scltpl@gmail.com. \\ ORCID: 0000-0001-9938-7513 \\ ORCID: 0000-0001-7829-7957 \\ ORCID: 0000-0002-5669-4932 \\ ORCID: 0000-0002-9164-3938 \\ *Sorumlu yazar/ Corresponding Author: Fatih Tekin \\ Gönderim Tarihi / Received: 14.05.2021 \\ Kabul Tarihi / Accepted: 23.05.2021 \\ DOI: $10.34087 /$ cbusbed. 937098 \\ $\ddot{\mathbf{O} z}$
}

Giriş ve Amaç: Çalışmaya 18-30 yaşları arasında 140 öğrenci (E: 60 K: 80) dâhil edildi. Katılımcılar düzenli egzersiz alışkanlığı olanlar (Grup I) ve olmayanlar (Grup II) olarak iki gruba ayrıldı. Katılımcıların yaş, cinsiyet, egzersiz alışkanlıkları, yıllık toplam telefon kullanım süresi ve günlük telefon kullanım süresi gibi bilgileri demografik veri formuna kaydedildi. Değerlendirmelerde Görsel Analog Skala ve Boyun Özür İndeksi kullanıldı.

Bulgular: Grup içi akıllı telefon kullanım süreleri açısından Grup I katılımcılarının gündüz, gece ve tüm gün kullandıkları akıllı telefon süreleri arasında anlamlı farklılık bulundu $(\mathrm{p}<0.05)$. Ağrı şiddeti ve boyun özür düzeyindeki artış gruplar arasında istatistiksel olarak anlamlı bulundu $(\mathrm{p}<0.05)$. Grup II'deki katılımcıların Görsel Analog Skala ve Boyun Özür İndeksi puanları Grup I'deki katılımcılardan daha yüksekti. Akıllı telefonu günde 6 saatten az kullanan gruplar arası Görsel Analog Skala ve Boyun Özür İndeksi skorları arasındaki fark yüksek düzeyde anlamlı bulundu $(\mathrm{p}=0.0001)$.

Sonuç: Genç popülasyonda akıllı telefon kullanımı kaynaklı boyun ağrısı ve özür düzeyini azaltmak için halk sağlı̆̆ açısından düzenli egzersiz alışkanlıklarının artırılması, gün içinde akıllı telefon kullanım süresinin kısaltılması ve telefon kullanımı sırasında ergonomik duruşun öğretilmesi gerektiğine inanıyoruz.

Anahtar kelimeler: Akıllı Telefon, Boyun Ağrısı, Boyun Özür İndeksi, Görsel Analog Skala, Üniversite Öğrencileri.

Abstract

Objective: This study was conducted to investigate the effect of smartphone use on neck pain and disability among university students who exercise regularly.

Materials and Methods: Hundred and forty students (M: 60 F: 80) between the ages of 18-30 years were included in the study. Participants were divided into two groups as those with regular exercise habits (Group I) and those without (Group II). Participants' information such as age, gender, exercise habits, total smartphone usage time per year and daily smartphone usage time were recorded in the demographic data form. Visual Analogue Scale and Neck Disability Index were used for the evaluations.

Results: In terms of the duration of smartphone use within the group, a significant difference was found between the duration of the smartphone used by the participants in Group I during the day, night and all day $(\mathrm{p}<0.05)$. The increase in pain intensity and neck disability level was found to be statistically significant between the groups $(p<0.05)$. Visual Analogue Scale and Neck Disability Index scores of the participants in Group II were higher than the participants in Group I. The differences in Visual Analogue Scale and Neck Disability Index scores were found to be highly significant between the groups who used the smartphone for less than 6 hours a day $(p=0.0001)$. 
Conclusion: In order to reduce the level of neck pain and neck disability due to smartphone use, we believe that increasing regular exercise habits, reducing the duration of smartphone use during the day and teaching ergonomic posture during smartphone use are necessary in terms of public health in the young population.

Keywords: Neck Disability Index, Neck Pain, Smartphone, Undergraduate, Visual Analogue Scale.

\begin{abstract}
1. Introduction
Today, there are rapid developments in communication technologies as in other areas of technology. Especially in the last decade, with the development of smartphone technology, mobile phones have become a part of the daily life of people from almost every part of the society. Because smartphones go beyond the purpose of communicating by phone, and can perform many tasks alone, such as using social media, browsing websites, paying bills, attending online conferences, making various applications, and using government services [1]. This may cause excessive use of smartphones in daily life [2]. Overuse of smartphones has also been shown to cause various problems like neck pain, neck disability and back pain on individuals
\end{abstract} [2].

It has been reported that as the functionality of mobile phones increases, people's dependence on mobile phones will become inevitable [3]. The largest user group of smartphones is the young and young adult population. According to a study conducted in Turkey in the dependency ratio of male college students on their smartphones while in women it is $26.7 \% 27.9 \%$ [4].

Overuse of smartphones has been reported to cause problems such as blurred vision, pain in the wrist, shoulder and neck, postural changes in the cervical and lumbar vertebrae, difficulty in maintaining the correct posture, deficits in cervical proprioception, anxietydepression and headache [5-8].

Health-related habits acquired in the early stages of life affect the risks of life-style disorders in the future [9]. Therefore, it becomes important to investigate health behaviors in young people. It has been shown that exercise habits in young adults also help prevent musculoskeletal problems that may arise in later ages [10].

This study was conducted to investigate the effect of smartphone use on neck pain and disability among university students who exercise regularly.

\section{Materials ve Methods}

\subsection{Study Desgin}

Our study is a descriptive study examining the effects of smartphone use on neck pain and disability on university students who exercise regularly and who do not. Fitness exercises were determined as the type of exercise accepted for the study, and participants who exercised regularly for at least 150 minutes or more per week were accepted into the exercise group. Participants included in the study were divided into Group I with regular exercise habits, and Group II, those without regular exercise habits. The results were analyzed by making the same evaluations to both groups. Due to the Covid-19 pandemic, participation in the study was done via e-mail.

\subsection{Participants}

Hundred and forty students (M: $60 \mathrm{~F}: 80$ ) between the ages of 18-30 years, studying at Pamukkale University School of Physical Therapy and Rehabilitation, were included in the study. Participation in the study was voluntary and consent forms were obtained from the participants via online method. Inclusion criteria; It is defined as being in the age range of 18-30 years, using a smartphone for at least 3 hours a day, having not had any surgical operations related to the neck area in the last 6 months, and not having any systemic or mechanical disease that may cause neck pain. Those who filled in the missing forms and did not want to participate in the study were excluded from the study. The study was conducted between June and December 2020 according to the Declaration of Helsinki, and it was decided by Pamukkale University NonInterventional Medical Ethics Committee with the number 60116787-020/38934 that there was no ethical drawback in conducting this study.

\subsection{Demographic Data}

Participants' information such as age, gender, exercise habits, total smartphone usage time per year and daily smartphone usage time were recorded in the demographic data form.

\subsection{Evaluation of Neck Pain}

The Visual Analogue Scale (VAS) was used to assess the intensity of neck pain and the participants were asked to mark the level of pain they felt in the neck area while using the smartphone. VAS is a 10-centimeter straight line and the number 0 (zero) on one end indicates the situation where no pain is felt, and the number 10 (ten) on the other end indicates the pain felt unbearably. The points marked by the participants were measured with the help of a ruler and recorded as numerical values [11]. Analyzes were made by categorizing the intensity of pain during smartphone use as mild $(0.1-3.9 \mathrm{~cm})$, moderate $(4-6.9 \mathrm{~cm})$, and severe ( $7 \mathrm{~cm}$ and above).

\subsection{Evaluation of Neck Disability}

Neck Disability Index (NDI) was used to evaluate the disability due to pain in the neck area. It is the first scale presented for disability due to neck pain and is widely used in the literature. This scale, which was created by Vernon and Mion (1991), is a modification of the Oswestry Low Back Pain and Disability Index, and is designed to evaluate how pain affects daily living activities [12]. There are 10 topics: pain intensity, personal care, lifting, reading, headache, concentration, work life, driving, sleep and rest. Each title is scored between no excuse (0) and complete excuse (5). The total score is between 0 and 50. An increase in the score 
indicates an increased disability [12]. Its Turkish validity and reliability study has been conducted [13]. 2.6. Statistical Analysis

According to the data obtained from the reference study [14], as a result of the power analysis performed considering the effect size $(r=0.4)$, it was calculated that $80 \%$ power at a $95 \%$ confidence level could be obtained when at least 126 people (at least 63 people for each group) were taken into the study. The data of the study were analyzed with SPSS 25.0 (IBM SPSS Statistics 25 software (Armonk, NY: IBM Corp.)) package program. Continuous variables are given as mean \pm standard deviation and categorical variables as numbers and percentages. In our study, our data were nonparametric according to the Shapiro Wilk test, and the differences between categorical variables in binary groups were examined with Chi-square McNemar analysis, and categorical variables in multiple groups were examined with the Kruskal Wallis test. Numerical variables in paired groups were analyzed by Mann Whitney U test. Significance level was accepted as $p<0.05$.

\section{Results and Discussion}

3.1.Results

The mean age of Group I was 23,45 $\pm 3,13$ years and Group II was $23,23 \pm 2,48$ years. In our study, $62.4 \%$ of the participants had mild neck pain. Information on the gender distribution of the participants and the duration of smartphone use are given in Table 1. In our study, the duration of daytime smartphone use of the participants in Group II was higher than that of Group $\mathrm{I}$, and the difference was found to be significant $(\mathrm{p}=0.005)($ Table 1$)$.

Table 1. Comparison of data on participants' smartphone use between groups

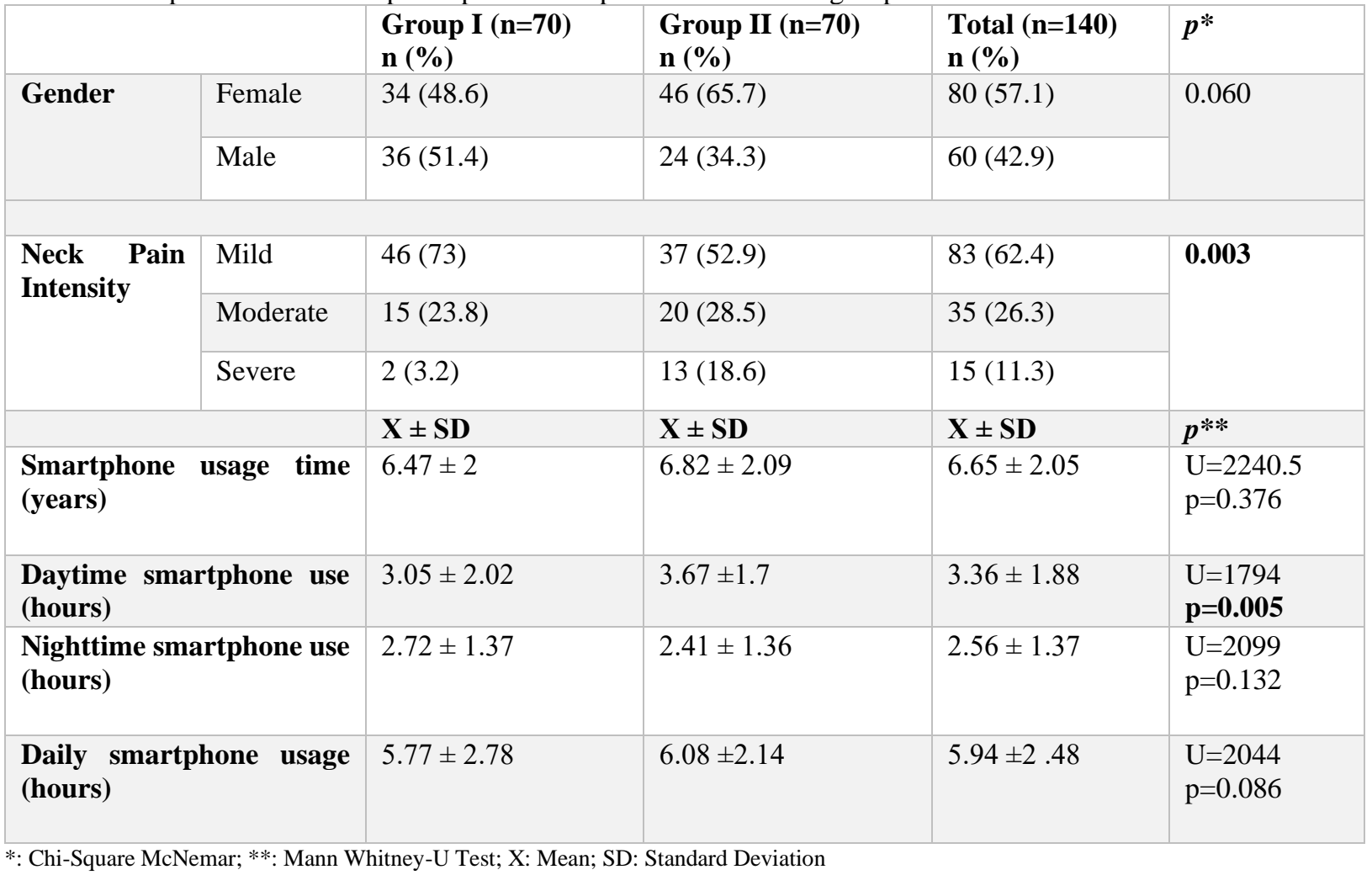

When the participants were categorized according to the intensity of neck pain, and compared in terms of the duration of smartphone use within the group, a significant difference was found between the duration of the smartphone used by the participants in Group I during the day, night and all day $(\mathrm{p}<0.05)$. Moderate and severe neck pain was found in participants who used the smartphone for more time during the day (Table 2).

Based on the median value of all participants per day (less than 6 hours, 6 hours and above), neck pain intensity and level of disability were examined within the group, it was observed that the duration of smartphone use of the participants in Group I was more than 6 hours a day. The increase in pain intensity and neck disability level was found to be statistically significant $(p<0.05)$. In group II, no significant difference was found in VAS and NDI scores between those who used it for less than 6 hours a day and those who used it for more than 6 hours ( $p>0.05)$ (Table 3 ).

Based on the median value of all participants (less than 6 hours, 6 hours or more), based on the median value of all participants per day, when the neck pain intensity and disability level data were examined, it was found that the VAS and NDI scores of the participants in Group II were higher than the participants in Group I. The difference was found to be highly significant between the groups who used the smartphone for less than 6 hours a day $(\mathrm{p}=0.0001)$ (Table 4$)$. 
Table 2. Comparison of the duration of smartphone use in the group according to the neck pain intensity of the participants

\begin{tabular}{|c|c|c|c|c|c|c|c|c|}
\hline \multirow[t]{3}{*}{ (2) } & \multicolumn{4}{|c|}{ Group I } & \multicolumn{4}{|c|}{ Group II } \\
\hline & Mild & Moderate & Severe & \multirow[t]{2}{*}{$\mathbf{p}^{*}$} & Mild & Moderate & Severe & \multirow[t]{2}{*}{$\mathbf{p}^{*}$} \\
\hline & $\mathrm{X} \pm \mathrm{SD}$ & $\mathrm{X} \pm \mathrm{SD}$ & $\mathrm{X} \pm \mathrm{SD}$ & & $\mathrm{X} \pm \mathrm{SD}$ & $\mathrm{X} \pm \mathrm{SD}$ & $\mathrm{X} \pm \mathrm{SD}$ & \\
\hline $\begin{array}{l}\text { Smartphone } \\
\text { usage time } \\
\text { (years) }\end{array}$ & $\begin{array}{l}6,35 \pm \\
1.91\end{array}$ & $6.8 \pm 2.45$ & $7 \pm 0.12$ & $\begin{array}{l}K W=0.755 \\
p=0.685\end{array}$ & $\begin{array}{l}6.81 \\
\pm 2.01\end{array}$ & $\begin{array}{l}7.15 \\
\pm 2.47\end{array}$ & $\begin{array}{l}6.38 \pm \\
1.75\end{array}$ & $\begin{array}{l}\mathrm{KW}=0.638 \\
\mathrm{p}=0.727\end{array}$ \\
\hline $\begin{array}{l}\text { Daytime } \\
\text { smartphone } \\
\text { use (hours) }\end{array}$ & $\begin{array}{ll}2.6 & \pm \\
1.16 & \end{array}$ & $4 \pm 3.04$ & $8 \pm 2.82$ & $\begin{array}{l}K W=6.945 \\
\mathbf{p}=\mathbf{0 . 0 3 9}\end{array}$ & $\begin{array}{l}3.51 \pm \\
1.6\end{array}$ & $4.05 \pm 1.9$ & $\begin{array}{l}3.53 \pm \\
1.66\end{array}$ & $\begin{array}{l}\mathrm{KW}=0.937 \\
\mathrm{p}=0.626\end{array}$ \\
\hline $\begin{array}{l}\text { Nighttime } \\
\text { smartphone } \\
\text { use (hours) }\end{array}$ & $\begin{array}{l}2.38 \pm \\
1.03\end{array}$ & $\begin{array}{l}3.66 \\
1.87\end{array}$ & $4.5 \pm 0.7$ & $\begin{array}{l}\mathrm{KW}=12.034 \\
\mathbf{p}=\mathbf{0 . 0 0 2}\end{array}$ & $\begin{array}{l}2.21 \\
\pm 1.13\end{array}$ & $2.4 \pm 1.53$ & $\begin{array}{l}3.07 \quad \pm \\
1.63\end{array}$ & $\begin{array}{l}\mathrm{KW}=2.171 \\
\mathrm{p}=0.338\end{array}$ \\
\hline $\begin{array}{l}\text { Daily } \\
\text { smartphone } \\
\text { usage } \\
\text { (hours) }\end{array}$ & $\begin{array}{l}4.99 \pm \\
1.45\end{array}$ & $\begin{array}{l}7.66 \\
4.09\end{array}$ & $\begin{array}{l}12.5 \\
3.53\end{array}$ & $\begin{array}{l}\mathrm{KW}=10.359 \\
\mathbf{p}=\mathbf{0 . 0 0 6}\end{array}$ & $\begin{array}{l}5.72 \\
\pm 1.85\end{array}$ & $\begin{array}{l}6.45 \\
\pm 2.35\end{array}$ & $\begin{array}{l}6.53 \pm \\
2.56\end{array}$ & $\begin{array}{l}\mathrm{KW}=1.181 \\
\mathrm{p}=0.541\end{array}$ \\
\hline
\end{tabular}

Table 3. Intragroup comparison of VAS and NDI scores according to daily smartphone usage time
Variables
Group I
Group II

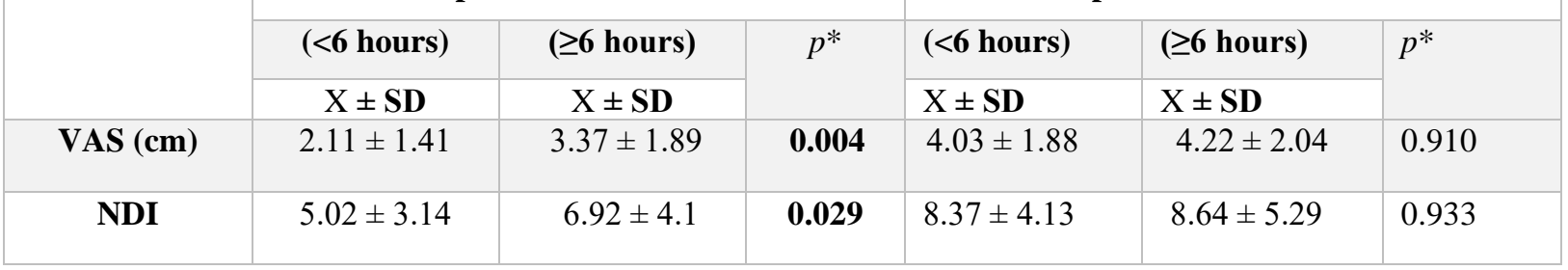

*: Mann Whitney-U Test; X: Mean; SD: Standard Deviation; VAS: Visual Analog Scale; NDI: Neck Disability Index

Table 4. Comparison of VAS and NDI scores between groups according to daily smartphone usage time

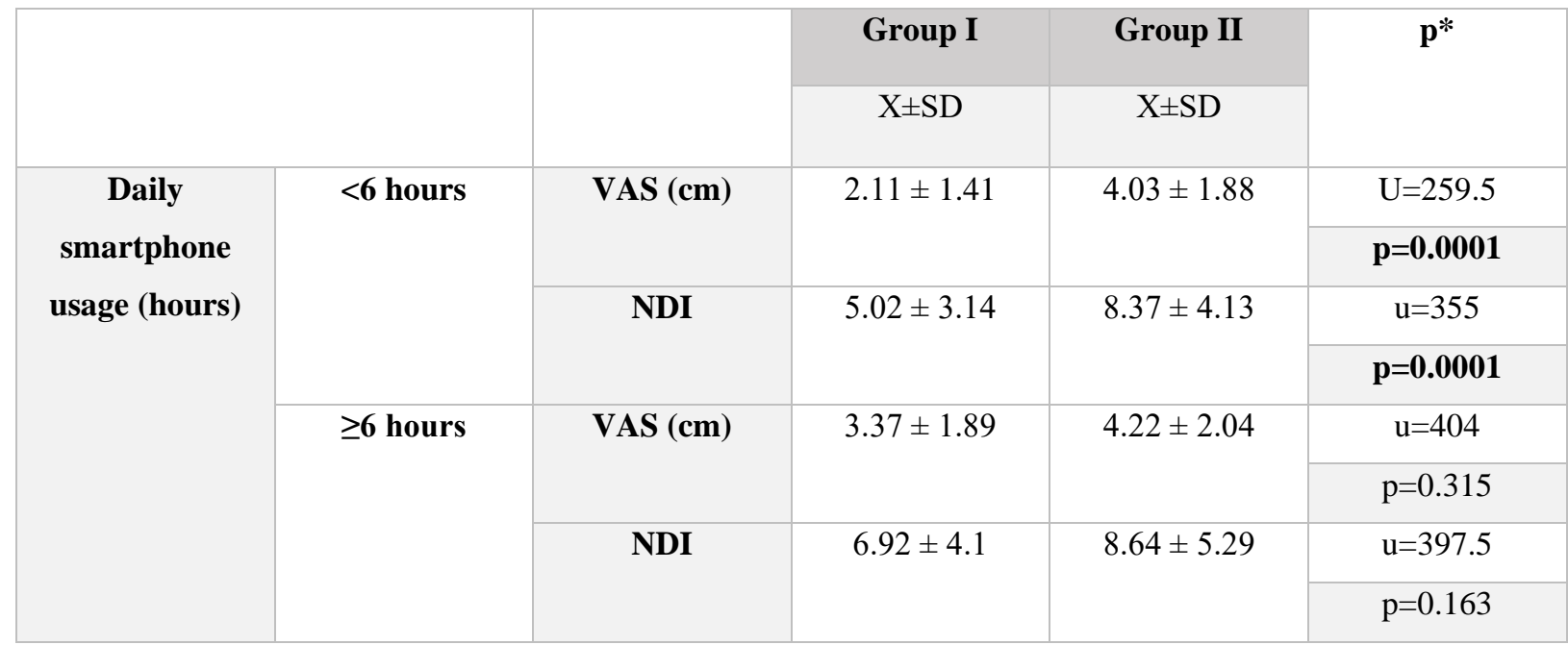

*: Mann Whitney-U Test; X: Mean; SD: Standard Deviation; ;VAS: Visual Analog Scale; NDI: Neck Disability Index

\subsection{Discussion}

In this study, in which we investigated the effect of smartphone use time and regular exercise on neck pain and disability level in university students, we found that the increase in the duration of smartphone use during the day and its use for many years caused neck pain. In addition, we thought that the students in the nonexercising group spent more time using their smartphone during the day, as the probable reason for the students who did exercise to devote some of their time to exercise. We also found that using smartphones for less than 6 hours increased the intensity of neck pain and the level of disability.

In our study, when the duration of smartphone use was examined according to the intensity of neck pain in the group that exercised regularly, it was found that the participants who had more daytime and nighttime smartphone usage hours had severe neck pain. When 
the literature is examined, it has been found that as the hours of smartphone use increase during the day, musculoskeletal pain increases and especially the neck area is affected by this situation, and its ratio among all musculoskeletal pain is as high as $68 \%[15,16]$.

The purpose of use of smartphones is not only for speaking, but also for messaging, internet use, social media tracking, and games. When viewed as body posture, all these activities are performed with head and neck flexion. Therefore, the muscular and joint structures in the neck area are extremely difficult to use for a long time [5]. Huber et al. Reported that mobile phone use caused changes in cerebral blood flow and electroencephalogram pattern [17]. In our study, we recorded the intensity of pain caused by the muscles around the neck during the use of smartphones, according to the participants' own statements, but using VAS, which is the most objective method of pain intensity assessment scales. We saw that the intensity of pain increased in participants who used smartphones for a long time. However, we found that in the group that exercised regularly, they were more affected by the duration of smartphone use during the day than those who did not. We can interpret this situation as the people who do regular fitness exercises are more resistant to injuries due to the stronger columna vertebralis muscles, stronger core stabilization and better body biomechanics. As a matter of fact, it is known that exercise creates physical well-being by increasing physical capacity $[18,19]$.

Using smartphones during the day has become a necessity in today's conditions. In a study, it was found that the use of smartphones as a means of internet access, social networks and game play was higher than the rate of making phone calls [20]. While using a smartphone makes our daily life easier, it can also cause physical and functional damage to our body without realizing it. It can cause problems such as neck, back, low back pain, repetitive injuries in the shoulder and fingers, kyphosis in the upper thoracic vertebrae, and decrease in cervical lordosis $[16,21]$. It is known that prolonged smartphone use damages muscle fibers as a result of repeated contractions of certain muscles, and this cumulative damage frequently creates myogenic tone in the neck and shoulder muscles [22]. The pain intensity is high in the muscles that remain in myogenic tone for a long time and it affects the person negatively physically and psychologically. In a study investigating the frequency of smartphone use, cervical flexion, pain, and clinical depression, they found that overuse increased stresses on the cervical spine, and the duration of use was associated with the pressure pain threshold in the sternocleidomastoid and upper trapezius muscles [16]. In another study, it was reported that the pressure pain threshold of the neck muscles was significantly lower in smartphone users compared to those who used less [23]. In a study involving patients with and without neck pain, a negative relationship was found between the use of smartphones and the pressure pain levels of the cervical erector spina and trapezius muscles [24]. When the participants who used a smartphone for at least 6 hours a day in our study were examined, it was found that the intensity of neck pain was higher in the group who did not exercise regularly. We found that using a smartphone for more than 6 hours a day did not increase the intensity of neck pain significantly, especially considering that it is a habitual one in young people. Although the pain threshold was not measured in our study, studies show that pain threshold and perception change in long-term use. We can interpret this finding as postural posture disorders are tolerated due to the young population of our participants, pain thresholds change, and perception may be less than those who exercise.

Long-term use of the smartphone during the day has been reported in the literature that not only changes the posture position in the cervical, thoracic and lumbar spine, but also changes the craniocervical angle, respiratory functions and postural balance abilities are negatively affected, that is, it causes physical disability $[14,25,26]$. In our study, we found that the use of smartphones for 6 hours a day significantly increased the level of neck disability in the group who did not exercise regularly compared to the group that did regular exercise. However, we found that using it for more than 6 hours, it affected only the exercising group and increased the level of disability and was more affected than the non-exercising group. In line with the literature, we can say that prolonged smartphone use increases the level of neck disability. However, we can interpret the fact that if it is used for more than 6 hours, it affects only the exercising group, and different factors may also affect the disability. Our limitations include not asking for detailed information about smartphone usage in our study, such as the screen size or not determining how many hours of smartphone use continuously. In addition, the fact that there is no homogeneity in terms of gender in the group that does not exercise may have affected our results because of the higher female population. The fact that the exercises our participants did regularly were not discussed in detail also prevented us from discussing the level of disability in detail. Considering the limitations of our study, we think that randomized controlled studies should be planned to investigate how exercise affects physical problems that may arise from smartphone use.

\section{Conclusion}

While our society and especially the young generation benefit from the facilities brought by technology uncontrollably, they may experience various health problems related to the use of smartphones over time. Families and healthcare professionals need to take the necessary precautions against the problems caused by the use of smartphones, and the use of smartphones, which goes back to the primary school age, should be purposeful and controlled. We think that it is important for public health to provide educational information about ergonomic posture positions and the frequency of 
their use, especially in young population, when using smartphones, from all media sources.

\section{References}

1. Demirci, K, Akgönül, M, Akpınar, A, Relationship of smartphone use intensity with sleep quality, depression, and anxiety in university students, Journal of Behavioral Addictions, 2015, 4(2), 85-92.

2. Aypay, A, Eryılmaz, A, Relationships of high school sdutent'subjective well-being and school burnout, International Online Journal of Educational Sciences, 2011, 3(1), 181-199.

3. Roberts, J.A, Yaya, L.H.P, Manolis, C, The invisible addiction: Cell-phone activities and addiction among male and female college students, Journal of Behavioral Addictions, 2014, 3(4), 254-265.

4. Türkiye İstatistik Kurumu, Erișim tarihi: 14 Nisan 2018 , http://www.tuik.gov.tr/HbPrint.do?id=24862

5. Kim, Y.G, Kang, M.Y, Kim, W.J, Jang, H.Y, Oh, J.S, Influence of the duration of smartphone usage on flexion angles of the cervikal and lumbar spine and on reposition error in the cervikal spine, Physical Therapy Korea, 2013, 20, 10-17.

6. Lee, J.I, Song, H.S, The correlation analysis between hours of smartphone use and neck pain in the Gachon University students, The Acupuncture, 2014, 31(2), 99-109.

7.Lemola, S, Perkinson-Gloor, N, Brand, S, Dewald-Kaufmann, J.F Grob, A, Adolescents' electronic media use at night, sleep disturbance, and depressive symptoms in the smartphone age, Journal of Youth and Adolescence, 2015, 44(2), 405-418.

8.Hwang, K.H, Yoo, Y.S, Cho, O.H, Smartphone overuse and upper extremity pain, anxiety, depression, and interpersonal relationships among college students, Korea Constents Association, 2012, 12(10), 365-375

9. Caspersen, C.J, Powell, K.E, Christenson, G.M, Physical activity, exercise, and physical fitness: definitions and distinctions for health-related research, Public Health Reports, 1985, 100(2), 126131.

10. Karabıçak, G..Ö, Ayaş ilçesindeki adolesanlarda fiziksel aktivite düzeyinin postür, ağrı ve anksiyete üzerine etkilerinin incelenmesi, 2014, Doktora, Hacettepe Üniversitesi.

11. Langley, G.B, Sheppeard, H, The visual analogue scale: its use in pain measurement, Rheumatology International, 1985, 5(4), 145148.

12. Vernon, H, Mior, S, The Neck Disability Index: a study of reliability and validity, Journal of Manipulative and Physiological Therapeutics, 1991, 14, 409-415.

13. Aslan, E, Karaduman, A, Yakut, Y, Aras, B, Simsek, IE, Yagli N, The cultural adaptation, reliability and validity of neck disability index in patients with neck pain: a Turkish version study, Spine, 2008, 33(11), E362-E365.

14. Al Abdulwahab, S.S, Kachanathu, S.J, AlMotairi, M.S Smartphone use addiction can cause neck disability, Musculoskeletal Care, 2017, 15(1), 10-12.

15. Berolo, S, Wells, R.P, Amick, B.C, Musculoskeletal symptoms among mobile hand-held device users and their relationship to device use: a preliminary study in a Canadian university population, Applied Ergonomics, 2011, 42(2), 371-378.

16. Park, J, Kim, K, Kim, N, Choi, I, Lee, S, Tak, S, A comparison of cervical flexion, pain, and clinical depression in frequency of smartphone use, International Journal of Bio-Science BioTechnology, 2015, 7(3), 183-190.

17. Huber, R, Treyer, V, Borbely, A.A, Schuderer, J, Gottselig, J.M, Electromagnetic fields, such as those from mobile phones, alter regional cerebral blood flow and sleep and waking EEG, Journal of Sleep Research, 2002, 11(4), 289-295 .

18. Mothes, H, Klaperski, S, Seelig, H, Schmidt, S, Fuchs, R, Regular aerobic exercise increases dispositional mindfulness in men: A randomized controlled trial, Mental Health and Physical Activity, 2014, 7, 111-119.

19. Williams, P.A, Cash, T.F, Effects of a circuit weight training program on the body images of college students, International Journal of Eating Disorders, 2001, 30(1), 75-82.

20. Keskin, T, Ergan, M, Başkurt, F, Başkurt, Z, Üniversite Öğrencilerinde Akıllı Telefon Kullanımı ve Baş Ağrısı İlişkisisi, Adıyaman Üniversitesi Sağlık Bilimleri Dergisi, 2018, 4(2), 864 873.
21. Lee, S, Kang, H, Shin, G, Head flexion angle while using a smartphone, Ergonomics, 2015, 58(2), 220-226.

22. Kim, S.Y, Koo, S.J, Effect of duration of smartphone use on muscle fatigue and pain caused by forward head posture in adults, Journal of Physical Therapy Science, 2016, 28(6), 1669-1672.

23. Park, J, Kim, J, Kim, J, Kim, K, Kim, N, Choi, I, The effects of heavy smartphone use on the cervical angle, pain threshold of neck muscles and depression, Advanced Science Technology Letters, 2015, 91(3), 12-17.

24. So, Y.J, Woo, Y.K, Effects of smartphone use on muscle fatigue and pain and, cervical range of motion among subjects with and without neck muscle pain, Physical Therapy Korea, 2014, 21(3), 28-37.

25. Lee, J, Seo, K, The comparison of cervical repositioning errors according to smartphone addiction grades, Journal of Physical Therapy Science, 2014, 26(4), 595-598.

26. Jung, S.I, Lee, N.K, Kang, K.W, Kim, K, Do, Y.L, The effect of smartphone usage time on posture and respiratory function, Journal of Physical Therapy Science, 2016, 28(1), 186-189.

http://edergi.cbu.edu.tr/ojs/index.php/cbusbed isimli yazarın CBU-SBED başlıklı eseri bu Creative Commons Alıntı-Gayriticari4.0 Uluslararası Lisansı ile lisanslanmıştır.

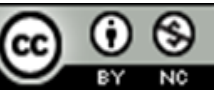

